\title{
Spatially explicit estimates of stock size, structure and biomass of North Atlantic albacore tuna (Thunnus alalunga)
}

\author{
P. Lehodey ${ }^{1}$, I. Senina ${ }^{1}$, A.-C. Dragon ${ }^{1}$, and H. Arrizabalaga ${ }^{2}$ \\ ${ }^{1}$ Marine Ecosystem Department, Space Oceanography Division, CLS Ramonville, 8-10 rue Hermès, 31520, \\ France \\ ${ }^{2}$ AZTI Tecnalia, Herrera kaia Portualdea z/g, 20110 Pasaia, Spain \\ Correspondence to: P. Lehodey (plehodey@cls.fr)
}

Received: 5 February 2014 - Published in Earth Syst. Sci. Data Discuss.: 14 April 2014

Revised: 23 July 2014 - Accepted: 5 August 2014 - Published: 19 September 2014

\begin{abstract}
The development of the ecosystem approach and models for the management of ocean marine resources requires easy access to standard validated data sets of historical catch data for the main exploited species. They are used to measure the impact of biomass removal by fisheries and to evaluate the models outputs, while the use of a standard data set facilitates models inter-comparison. Unlike standard stock assessment models, new state-of-the-art ecosystem models require geo-referenced fishing data with the highest possible spatial resolution. This study presents an application to the North Atlantic albacore tuna stock with a careful definition and validation of a spatially explicit fishing data set prepared from publicly available sources (ICCAT) for its use in a spatial ecosystem and population dynamics model (SEAPODYM) to provide the first spatially explicit estimate of albacore density in the North Atlantic by life stage. Density distributions together with the fishing data used for the estimates are provided at http://doi.pangaea.de/ (see section Source Data References) (doi:10.1594/PANGAEA.828115; doi:10.1594/PANGAEA.828226; doi:10.1594/PANGAEA.828227; doi:10.1594/PANGAEA.828228; doi:10.1594/PANGAEA.828229; doi:10.1594/PANGAEA.828230; doi:10.1594/PANGAEA.828231; doi:10.1594/PANGAEA.828232; doi:10.1594/PANGAEA.828233; doi:10.1594/PANGAEA.828234; doi:10.1594/PANGAEA.828235; doi:10.1594/PANGAEA.828236; doi:10.1594/PANGAEA.828237; doi:10.1594/PANGAEA.828238; doi:10.1594/PANGAEA.828168; doi:10.1594/PANGAEA.828170; doi:10.1594/PANGAEA.828171).
\end{abstract}

\section{Introduction}

Industrial fishing of albacore tuna (Thunnus alalunga) in the North Atlantic started after the Second World War. Since albacore is a highly migratory species inhabiting both international waters and various exclusive economic zones (EEZs), its management is conducted through international organizations, like the International Commission for the Conservation of Atlantic Tunas (ICCAT: http://www.iccat.org) for the Atlantic Ocean. Stock assessment studies conducted by these management bodies have tried to reconstruct the past history of the stock, based on biological knowledge and the use of fishing data (catch, effort and size frequency of catch), to ac- count for fishing mortality and to statistically fit the stock assessment models.

These standard stock assessment studies focused on temporal dynamics of the stock and the computation of fishing mortality. There is a lack of comprehensive understanding of the spatial structure and biomass dynamics of this species, as proposed in the objective of a large pluri-disciplinary research project like EURO-BASIN (www.euro-basin.eu) for the study on "climate and human forcing, ecosystem impact and consequences for living resources management in the North Atlantic". The model SEAPODYM (Spatial Ecosystem And Populations Dynamics Model) was used to fill this gap (Dragon et al., 2014). 
SEAPODYM describes the spatial dynamics of both the micronekton functional groups (Lehodey et al., 2010a) and the detailed age-structured populations of their predators like tunas (Lehodey et al., 2008) with a system of advection-diffusion-reaction equations and environmental forcing (temperature, currents, primary production and dissolved oxygen concentration). SEAPODYM also predicts catch and size frequency of catch by fleet when fishing data (catch and effort) are available, and these data are fitted with a maximum likelihood estimation (MLE) procedure to achieve optimal parameterization of the model (Senina et al., 2008). In contrast with standard stock assessment models, these fishing data are spatially disaggregated, the highest possible resolution being the one used for the model grid. Different life stages are considered in the age-structured populations: larvae, juveniles, and immature and mature adults. After the juvenile phase, fish become autonomous, i.e., they have their own movement (linked to their size and habitat) in addition to being transported by oceanic currents. Fish are considered immature until pre-defined age at first maturity and mature after this age, i.e., contributing to the spawning biomass, and with their displacements controlled by a seasonal switch between feeding and spawning habitat.

Here we present the results of this approach to estimate the stock size and population structure of albacore tuna and provide distributions of albacore density in the North Atlantic by life stage, together with the fishing data used for the estimate.

\section{Data}

The application of SEAPODYM to North Atlantic albacore was performed with oceanic variables (temperature currents, primary production, euphotic depth and dissolved oxygen concentration) provided at a resolution of $2^{\circ} \times$ month from the ocean circulation model NEMO (http:// www.nemo-ocean.eu/) coupled to the biogeochemical model PISCES (Pelagic Interaction Scheme for Carbon and Ecosystem Studies; Aumont and Bopp, 2006) and forced by the NCEP/NCAR atmospheric reanalysis for the period 19602008 (http://www.cgd.ucar.edu/cas/catalog/reanalysis/index. $\mathrm{html})$. These models have been extensively validated elsewhere and realistically simulate seasonal to interannual and decadal physical and biogeochemical ocean variability (Lengaigne et al., 2003; Gorgues et al., 2005; Bopp et al., 2005; Aumont and Bopp, 2006). However, the spatial resolution used here is too coarse to resolve mesoscale features and coastal upwelling regions.

The fishing data (catch, fishing effort and size frequencies of catch) of Atlantic tunas by gear, region and flag declared to ICCAT are available on its web site (http://www. iccat.es/en/accesingdb.htm). These raw data were checked and processed to prepare a fishing data set by fishery for SEAPODYM albacore application. This data set (ASCII) is provided together with estimated gridded albacore tuna density by life stage (NetCDF) on PANGAEA (see section Source Data References).

\subsection{Catch and effort}

North Atlantic tuna is exploited all year round by longline fisheries, mainly from Japan, Taiwan and the Republic of Korea, targeting subadult and adult albacore, and surface fisheries (Spain, France, Ireland and Portugal) targeting mainly immature and subadult fish in the Bay of Biscay and adjacent waters of the northeast Atlantic (Celtic Sea) in summer and autumn. All together these fisheries represented $98 \%$ of the total catch declared to ICCAT between 1960 and 2008 (Fig. 1). Venezuela, Panama, Belize and the Caribbean countries (Cuba, Trinidad and Tobago, the Dominican Republic, Grenada, Barbados, Saint Lucia and Bermuda) contributed to the remaining catch $(1.9 \%)$, mostly by longlining. Longline fishing effort decreased in the 1970s and 1980s due to a shift towards targeting of tropical tuna for the sashimi market, as illustrated by the decline of the albacore/bigeye price ratio from $\sim 1 / 1$ in the 1960 s to $\sim 1 / 3$ in the 2000 s (Fonteneau, 2008). Total reported landings for the North Atlantic generally began to decline after the 1960 s, due to a reduction of fishing effort by the traditional surface (troll and baitboat) fisheries, and since 1986 in the case of longline (ICCAT, 2010). New surface fisheries (drift net and mid-water pair pelagic trawl) developed in the 1990s.

ICCAT also maintains a database with monthly tuna catch and effort provided with geographical coordinates at monthly spatial resolution of $1^{\circ}$ or $5^{\circ}$ squares. These data were extracted to be used for the optimization of the model SEAPODYM. Given the broad spatial resolution available for Spanish fleets, additional files at higher resolution were provided by AZTI Tecnalia. Geo-referenced catch effort data exist in the ICCAT database for the most important fisheries, but there is a lack of information in the early years, and for less important fisheries (ICCAT, 2013a). The catch effort data available with positional information in the database can represent a fraction or the entire total catch for a given fleet. Over the period 1960-2007, spatially disaggregated data represented on average $\sim 25 \%$ of the total catch, with low percentages in the 1960s (2.8-24.8\%) but higher values in the following decades, in the range of $10.8-46.9 \%$ (Table 1; Fig. 1). While the data set was sufficient to optimize the habitats and movements and population dynamics parameters (Dragon et al., 2014), the fishing mortality in the simulation was consequently underestimated, though there are potential compensatory mechanisms at play in the optimization that can partly account for the total fishing effect as expressed in the data even if none of the catch is included (see Discussion).

Careful data screening led to the exclusion of a few obvious errors (e.g., with geographical coordinates on land). Fishery records for the Spanish Canary Islands had only few (110) records with both catch and effort together and thus 
Table 1. Total annual catch 1960-2008 (tonnes) used in SEAPODYM North Atlantic albacore simulation compared with total annual catch by all fisheries declared in the ICCAT database. Difference in tonnes and corresponding percentage of coverage.

\begin{tabular}{|c|c|c|c|c|c|c|c|c|c|}
\hline Year & $\begin{array}{r}\text { Catch in } \\
\text { SEAPODYM }\end{array}$ & $\begin{array}{r}\text { Total } \\
\text { ICCAT }\end{array}$ & Difference & $\%$ & Year & $\begin{array}{r}\text { Catch in } \\
\text { SEAPODYM }\end{array}$ & $\begin{array}{r}\text { Total } \\
\text { ICCAT }\end{array}$ & Difference & $\%$ \\
\hline 1960 & 1588 & 52869 & 51281 & 3.00 & 1985 & 15190 & 40826 & 25636 & 37.21 \\
\hline 1961 & 1203 & 42730 & 41527 & 2.82 & 1986 & 20553 & 47554 & 27001 & 43.22 \\
\hline 1962 & 5950 & 58787 & 52836 & 10.12 & 1987 & 9429 & 38115 & 28686 & 24.74 \\
\hline 1963 & 10463 & 60340 & 49877 & 17.34 & 1988 & 5489 & 33059 & 27570 & 16.60 \\
\hline 1964 & 16024 & 64634 & 48610 & 24.79 & 1989 & 3475 & 32071 & 28595 & 10.84 \\
\hline 1965 & 10626 & 60658 & 50032 & 17.52 & 1990 & 5652 & 36881 & 31229 & 15.33 \\
\hline 1966 & 5930 & 47363 & 41433 & 12.52 & 1991 & 7964 & 27931 & 19968 & 28.51 \\
\hline 1967 & 10105 & 59142 & 49037 & 17.09 & 1992 & 6638 & 30851 & 24213 & 21.52 \\
\hline 1968 & 10475 & 45220 & 34746 & 23.16 & 1993 & 8928 & 38135 & 29207 & 23.41 \\
\hline 1969 & 6916 & 46730 & 39814 & 14.80 & 1994 & 10172 & 35163 & 24992 & 28.93 \\
\hline 1970 & 11945 & 45895 & 33950 & 26.03 & 1995 & 7550 & 38377 & 30828 & 19.67 \\
\hline 1971 & 12090 & 56821 & 44731 & 21.28 & 1996 & 5646 & 28803 & 23156 & 19.60 \\
\hline 1972 & 8803 & 48781 & 39978 & 18.05 & 1997 & 5158 & 29023 & 23865 & 17.77 \\
\hline 1973 & 12678 & 45700 & 33022 & 27.74 & 1998 & 9789 & 25746 & 15957 & 38.02 \\
\hline 1974 & 13512 & 49606 & 36094 & 27.24 & 1999 & 10686 & 34551 & 23865 & 30.93 \\
\hline 1975 & 11870 & 41888 & 30018 & 28.34 & 2000 & 7894 & 33124 & 25230 & 23.83 \\
\hline 1976 & 23211 & 57235 & 34024 & 40.55 & 2001 & 12321 & 26253 & 13932 & 46.93 \\
\hline 1977 & 20027 & 54031 & 34004 & 37.07 & 2002 & 7820 & 22741 & 14922 & 34.39 \\
\hline 1978 & 17994 & 50121 & 32127 & 35.90 & 2003 & 9788 & 25567 & 15778 & 38.29 \\
\hline 1979 & 15362 & 51372 & 36010 & 29.90 & 2004 & 9494 & 25960 & 16466 & 36.57 \\
\hline 1980 & 7777 & 38691 & 30914 & 20.10 & 2005 & 12136 & 35318 & 23182 & 34.36 \\
\hline 1981 & 9641 & 34531 & 24890 & 27.92 & 2006 & 7268 & 36989 & 29721 & 19.65 \\
\hline 1982 & 14124 & 42673 & 28549 & 33.10 & 2007 & 3365 & 21991 & 18626 & 15.30 \\
\hline 1983 & 15471 & 51490 & 36020 & 30.05 & $2008 *$ & 1302 & 20483 & 19181 & 6.36 \\
\hline 1984 & 17572 & 41800 & 24228 & 42.04 & & & & & \\
\hline
\end{tabular}

* Incomplete data for this year.

were not included. Fisheries were defined first based on the fishing gear and the fishing country. Fishing effort on albacore decreased drastically in the early 1970 s in the longline Asian fleets due to the introduction of monofilament longline fishing gear and a change in the target species, with bigeye tuna becoming increasingly fished in relation to the development of the sashimi market. Based on catch series, the change seems to have occurred earlier in Japanese (after 1972) than in Korean (after 1979) and Taiwanese (after 1986) longline fishery. For the latter, the change was also associated with a spatial shift of fishing grounds. Therefore, a strong pattern existed in the distribution of catch (Fig. 2) showing well-developed longline fisheries in the whole North Atlantic Basin in the first part of the historical fishing period (before 1986) but declining in the more recent period (after 1986). The fishing ground for the surface fisheries in the northeast Atlantic tended to retract and concentrate in the Bay of Biscay. To keep the most homogeneous definition possible for fisheries in relation to their fishing gear, catchability for the Asian longline fisheries have been subdivided into two periods (Table 2). In total, and excluding the Canary Islands fishery, 13 fisheries were defined for the period 1956-2010 (Table 2), with fishing gears, longline, troll, mid-water trawl and bait fishing. Temporal resolution was monthly and the spatial resolution either 1 or $5^{\circ}$ square.

As indicated above, the level of coverage for spatially disaggregated fishing data was much lower than the total catch, though it was highly variable from one fishery to another. Figure 3 compares these two data sets for the six main fisheries (> $98 \%$ of total catch declared to ICCAT). Japanese and Taiwanese longline fleets appear complete, while other longline fleets (the Republic of Korea; USA) were partially covered (Fig. 3). Indeed, it is very likely that complete coverage of spatially geo-referenced catch and effort were due to extrapolation from geo-referenced catch and effort samples before submission to ICCAT, but this extrapolation was not produced for the other fleets. Though the size of actual samples would be useful information, it may be difficult to recover it for all the historical fishing period. For surface gears, the coverage from geo-referenced catch and effort is $7.3 \%$ of total catch available for the Spanish fleets and $23 \%$ for the French ones. Part of these gaps is due to the coarse resolution of the model grid that cannot include coastal zones where significant catch by Spanish fleets occurred. The catch for the Canary Islands in one single cell was also not included due to the lack of effort data. Finally, the southern boundary of 
Table 2. Revised definition of fisheries for the North Atlantic albacore ( $E$ : effort; $C$ : catch) to be used for SEAPODYM application. LL: longline; TROL: trolling; MWTD: mid-water trawling; BB: baitboat pole and line; Tro: tropical; subTro: subtropical; t: metric tonnes.

\begin{tabular}{|c|c|c|c|c|c|c|}
\hline Fishery & $\begin{array}{l}\text { Country } \\
\text { code }\end{array}$ & Gear & $\begin{array}{l}\text { Time } \\
\text { period }\end{array}$ & $\begin{array}{l}\text { Catch unit/ } \\
\text { effort unit }\end{array}$ & $\begin{array}{l}\text { No. of } \\
\text { CE data }\end{array}$ & $\begin{array}{l}\text { Resolution } \\
\quad \text { (deg) }\end{array}$ \\
\hline L1 & Japan & LL & $1956-1972$ & no. $(\text { no. hooks })^{-1}$ & 5481 & 5 \\
\hline L2 & Japan & LL & $1973-2010$ & no. $(\text { no. hooks) })^{-1}$ & 15734 & 5 \\
\hline L3 & USA & LL & $1987-2010$ & no. $(\text { no. hooks })^{-1}$ & 69200 & 1 \\
\hline $\mathrm{L} 4$ & Taiwan-subTro & LL & 1967-1986 & no. $(\text { no. hooks })^{-1}$ & 2527 & 5 \\
\hline L5 & Taiwan-Tro & LL & 1967-1986 & no. $(\text { no. hooks })^{-1}$ & 935 & 5 \\
\hline L6 & Taiwan-subTro & LL & $1987-2007^{a}$ & $\mathrm{t}(\text { no. hooks })^{-1}$ & 343 & 5 \\
\hline L7 & Taiwan-Tro & LL & $1987-2007^{\mathrm{a}}$ & $\mathrm{t}(\text { no. hooks })^{-1}$ & 514 & 5 \\
\hline L8 & the Republic of Korea & LL & 1966-1979 & $\mathrm{kg}(\text { no. hooks })^{-1}$ & 1928 & 1 \\
\hline L9 & the Republic of Korea & LL & $1980-2010$ & $\operatorname{kg}(\text { no. hooks })^{-1}$ & 4495 & 5 \\
\hline $\mathrm{T} 10$ & France & TROL & 1967-2009 & no. $(\text { no. sets })^{-1}$ & 6289 & 1 \\
\hline $\mathrm{T} 11$ & France & MWTD & $1989-2007^{\mathrm{a}}$ & $\operatorname{kg}(\text { no. sets })^{-1}$ & 605 & 1 \\
\hline B12 & Spain & TROL & $1987-2005^{\mathrm{a}}$ & no. $(\text { no. sets })^{-1}$ & 2856 & 1 \\
\hline B13 & Spain & $\mathrm{BB}$ & $1987-2005^{\mathrm{a}}$ & no. $(\text { no. sets })^{-1}$ & 1644 & 1 \\
\hline B14 & Spain-Canary ${ }^{\mathrm{b}}$ & BB & 1975-2010 & $\mathrm{kg}(\text { day at sea })^{-1}$ & 110 & 1 \\
\hline
\end{tabular}

a Catch and effort data from recent years not yet available from the ICCAT database.

b Not used.

Units are those of ICCAT database. For SEAPODYM simulation catch have been converted in tonne or in number of fish.

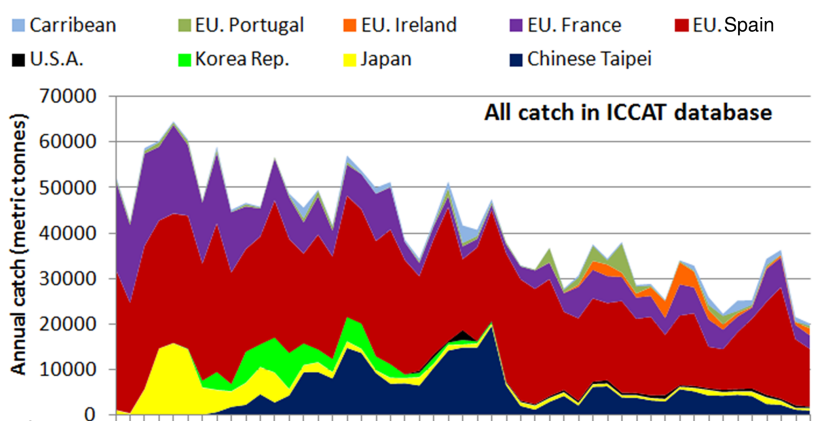

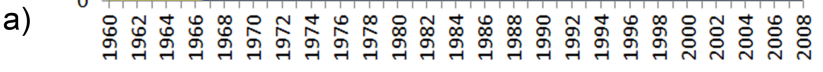

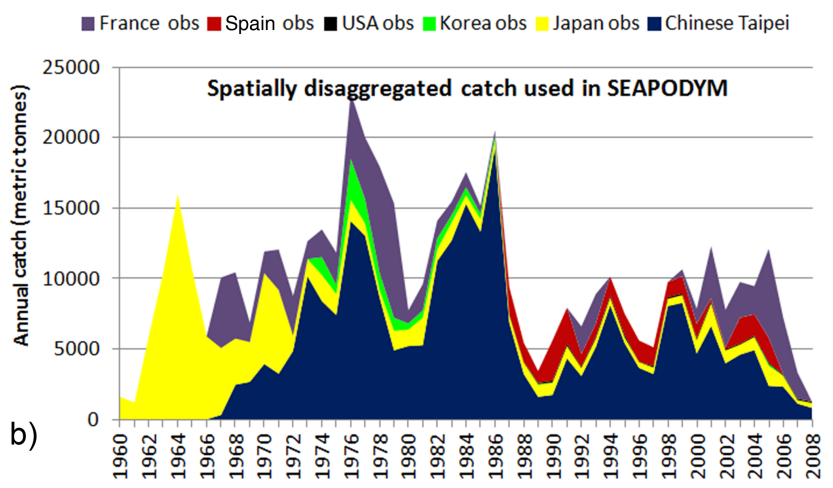

Figure 1. Annual catch of North Atlantic albacore tuna by flag. (a) All aggregated catch declared to ICCAT, and (b) available georeferenced catch data used with SEAPODYM. the North Atlantic stock for ICCAT was $5^{\circ} \mathrm{N}$, while it was the Equator for the SEAPODYM domain. This explains the higher catch level of Chinese Taipei longline fishery used in SEAPODYM after 1987 compared to the ICCAT total catch series.

\subsection{Size frequency of catch}

Length frequencies of catch for North Atlantic albacore were also available from the ICCAT database. They were extracted according to the definition of fisheries for the period 1956 2010 , with a quarterly temporal resolution and spatial resolutions varying from $1^{\circ} \times 1^{\circ}$ to $10^{\circ} \times 20^{\circ}$ (Fig. 4). The resolution used to measure the fish also varied with size bins of 1,2 or $5 \mathrm{~cm}$ (fork length - FL). The screening of data allowed for inconsistencies to be detected with a relatively large number of samples larger than $150 \mathrm{~cm}$, while all studies on the growth of albacore suggest that fish rarely grow to over $130 \mathrm{~cm}$. Given that SEAPODYM uses a single average size-at-age value by cohort and does not yet allow for growth variability around this value to be included, a threshold value of $130 \mathrm{~cm}$ has been arbitrarily fixed and all length frequency data above this value removed from the original data set. In addition, since the presence of fish larger than $130 \mathrm{~cm}$ in a given sample may indicate a problem in species identification by the observer, a precautionary approach was followed with a data filter to remove the whole sample (i.e., all size data collected from the same boat, date and area). The number of remaining samples in ICCAT dataset was well distributed over the entire fishing ground and increased in the second half of the fishing period (Fig. 4). 

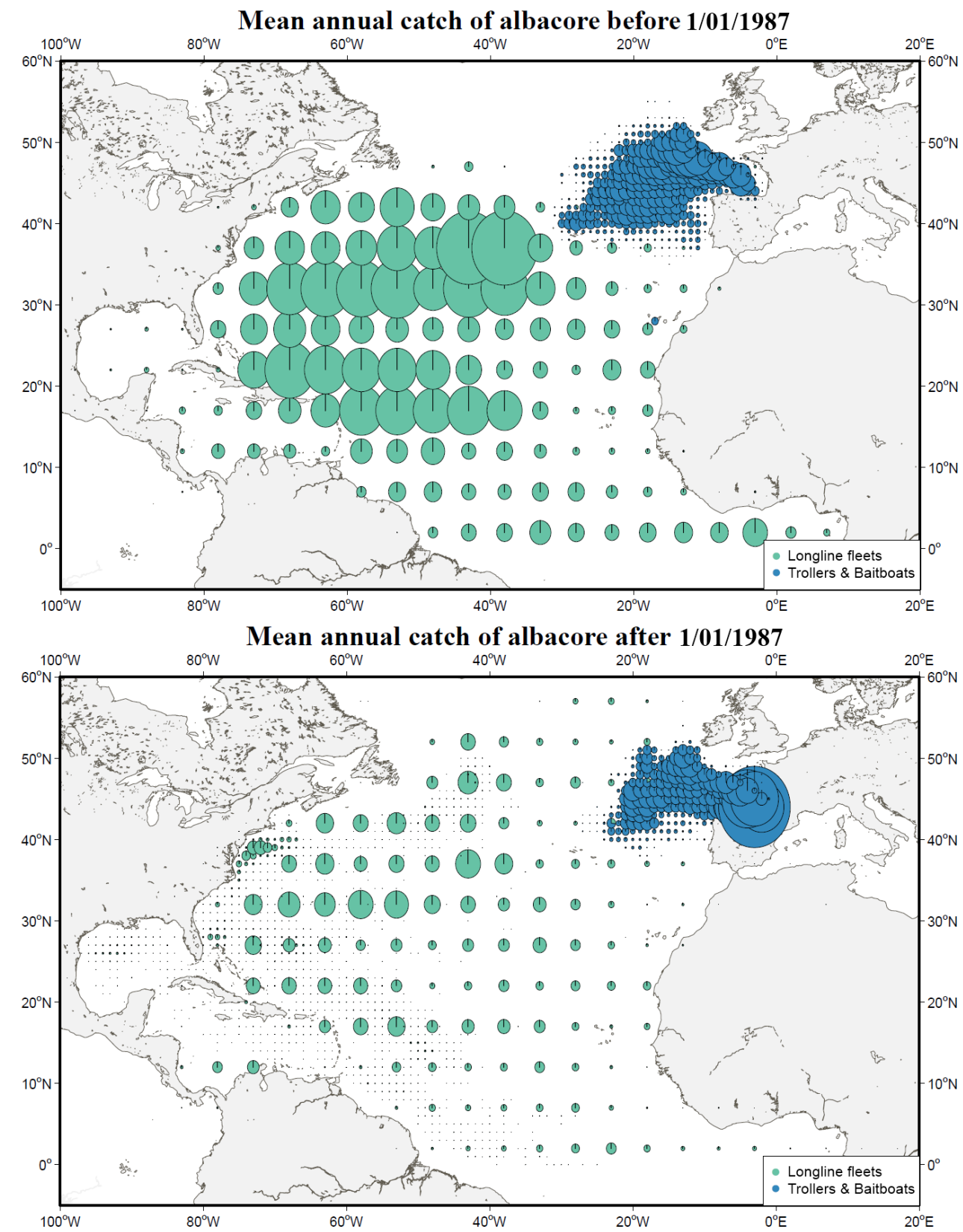

Figure 2. Spatial distribution of mean annual catch of North Atlantic albacore by longline (green) and surface (blue) fishing gears during the periods 1960-1986 and 1987-2008. The circles are proportional to the catch, with the same scale for both panels.

\section{North Atlantic albacore population dynamics}

\subsection{Life cycle and population age structure}

As with other tuna species, albacore are multiple or batch spawners, releasing millions of eggs of small size $(\sim 1 \mathrm{~mm})$. A few days after spawning, hatching larvae start to feed on microzooplankton, and the growth is fast in warm waters (above $24^{\circ} \mathrm{C}$ ). A review of scientific literature on albacore growth studies indicated very close weight-at-size relationships regardless of the oceanic region (Fig. 5a). The size- weight relationship selected is the allometric relationship $W=a L^{b}$, with $W$ the weight $(\mathrm{kg}), L$ the fork length $(\mathrm{cm})$, and $a$ and $b$ the two coefficients (respectively $6.959 \times 10^{-6}$ and 3.2351) estimated by Hoyle and Davies (2009).

There are more discrepancies between size-at-age estimates. In addition, due to the lack of samples in the range $0-40 \mathrm{~cm}$, none of the growth studies can correctly represent the growth of albacore during the early life stage, i.e., roughly the first year of life. The integrated growth study from Santiago and Arrizabalaga (2005) was first used to 

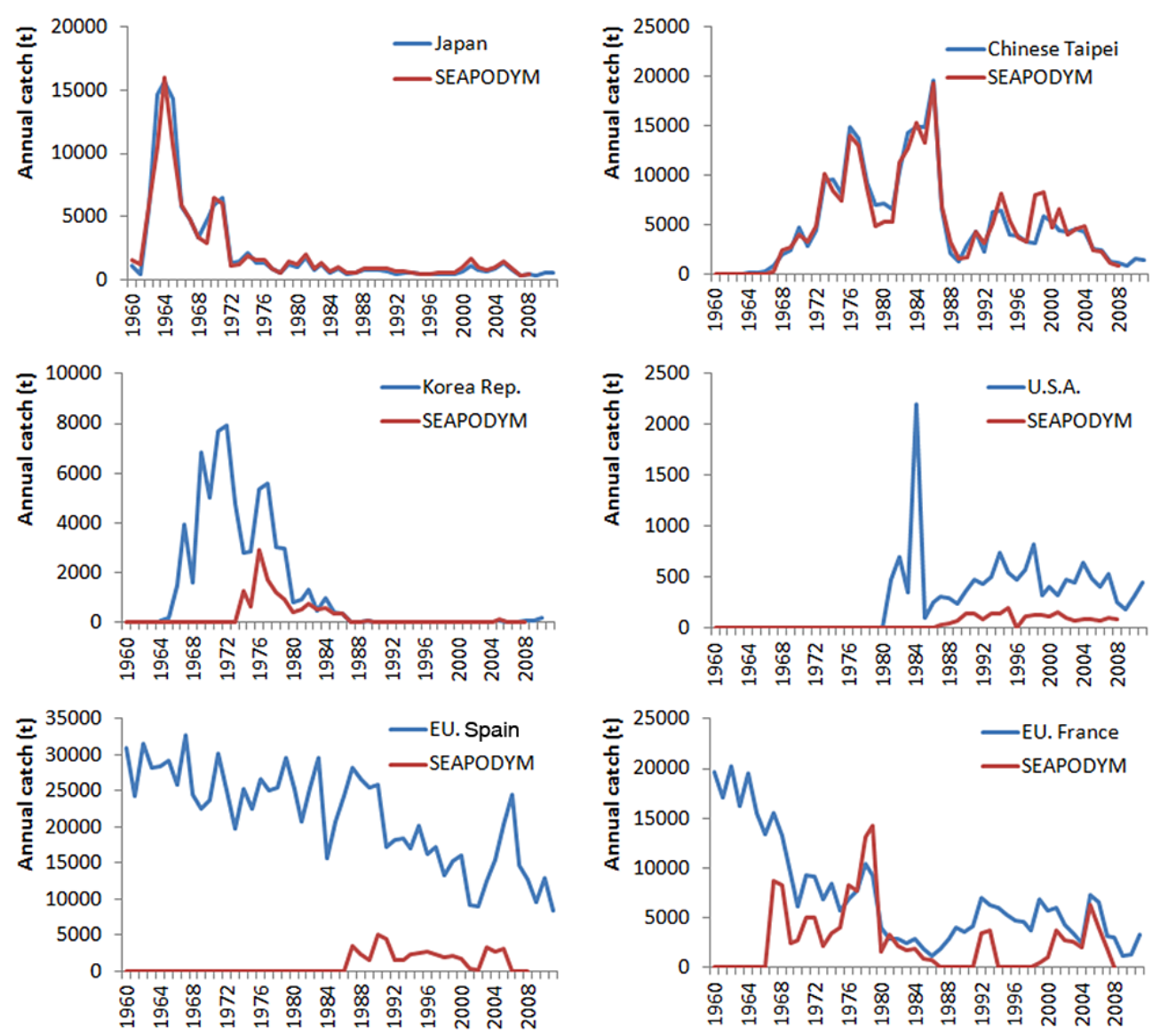

Figure 3. Time series of annual catch data with geographical coordinates used in the simulation with SEAPODYM and total annual catch declared to ICCAT for the main North Atlantic albacore tuna fisheries over the historical fishing period. When data were declared in number of fish, a conversion factor has been used, i.e., $16 \mathrm{~kg} \mathrm{fish}^{-1}$ for Japanese, Chinese Taipei and US longline, and $8 \mathrm{~kg}$ fish ${ }^{-1}$ for French and Spanish surface fisheries.

parameterize the age structure, but produced inconsistencies between the value of $L_{\infty}=122 \mathrm{~cm}$ FL and the length frequency samples. Despite the threshold value being set to $130 \mathrm{~cm}$ (cf. above), there were still a very large proportion of fish larger than $L_{\infty}$. An intermediate solution was selected with $L_{\infty}$ set to $137 \mathrm{~cm}$ FL, while a linear growth was assumed during the first year of life (Fig. 5b). Given the form of the function, the $L_{\infty}$ value of $137 \mathrm{~cm}$ gives a size of $130 \mathrm{~cm}$ for 15 -year-old fish. Therefore, though there are no size data above $130 \mathrm{~cm}$ used in the model optimization approach, a very small fraction of the population is assumed to reach sizes between 130 and $137 \mathrm{~cm}$ after 15 years of age (mean size of the "+ cohort" $=132.7 \mathrm{~cm}$ ).

There is still some uncertainty on sexual maturity, with the first maturity estimated to occur at sizes between 75 and $85 \mathrm{~cm}$ FL (Lam Hoai, 1970; Hayasi et al., 1972), with $50 \%$ of fish mature at $90 \mathrm{~cm}$ at an age of 5 years (Bard, 1981). The first age at maturity was set to 4.5 years $(84 \mathrm{~cm})$. Thus the structure of the population was defined with 157 cohorts, a 1 month cohort for the larval life stage, two monthly co- horts for the juvenile stage, 51 monthly cohorts for young immatures (age 3 months to 4.5 years), 102 monthly cohorts for adults and a last "+ cohort" accumulating older fish after 13 years of age).

\subsection{Estimates of abundance distributions}

The model simulates the distributions of cohorts in number of individuals, but outputs are aggregated by life stage (Fig. 6). Larvae and juvenile densities are in number of individuals, while for young and adult stages they are converted to $\mathrm{gm}^{-2}$ using age-size and size-weight relationships (Fig. 5). The North Atlantic albacore population was predicted to extend between the Equator and $60^{\circ} \mathrm{N}$, in agreement with catch data distribution. The main spawning ground was predicted within the subtropical and tropical warm waters. Though there is continuous spawning activity all year round in the tropical waters, there was a peak of activity in the second quarter in the Sargasso Sea, coinciding with the seasonal displacement of a large portion of the adult mature fish contracting from its maximal northern extension at 
a)
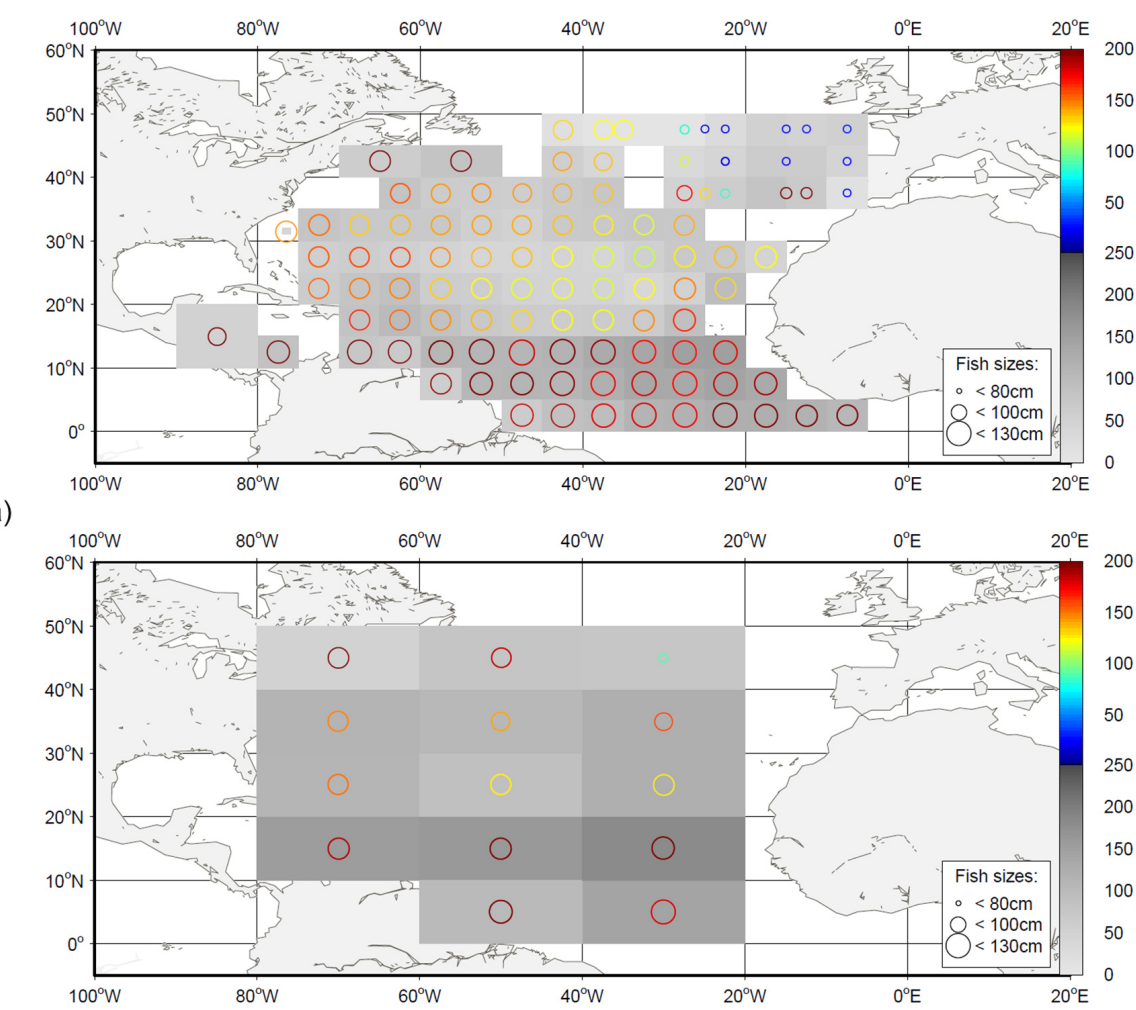

b)
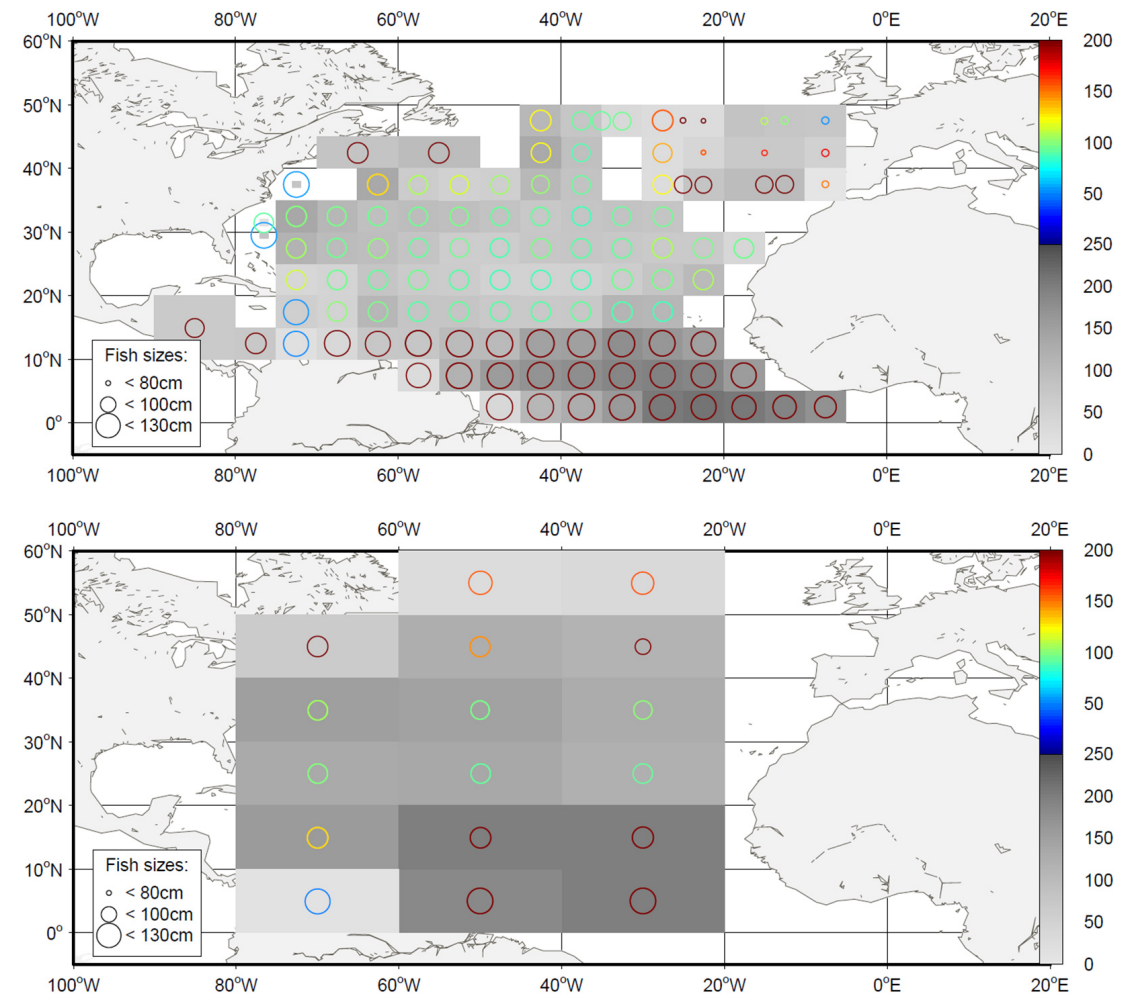

Figure 4. Length frequency data before (a) and after (b) January 1987. The data samples are aggregated at different spatial resolutions illustrated by rectangles with grey shading proportional to the number of samples (black and white color bar from 0 to 200 samples). In the center of each region, a circle gives the predicted mean size of fish (the larger the circle, the larger the mean size of fish in the catches) and the variance associated with this mean (color bar). Data are presented for high (top) and medium (bottom) resolution. The low-resolution data (three geographical boxes: $90^{\circ} \mathrm{W}-10^{\circ} \mathrm{E} ; 30-6^{\circ} \mathrm{N}, 80^{\circ} \mathrm{W}-0^{\circ} ; 60-30^{\circ} \mathrm{N}, 60^{\circ} \mathrm{W}-20^{\circ} \mathrm{E} ; 6^{\circ} \mathrm{N}-30^{\circ} \mathrm{S}$ ) are not shown. 

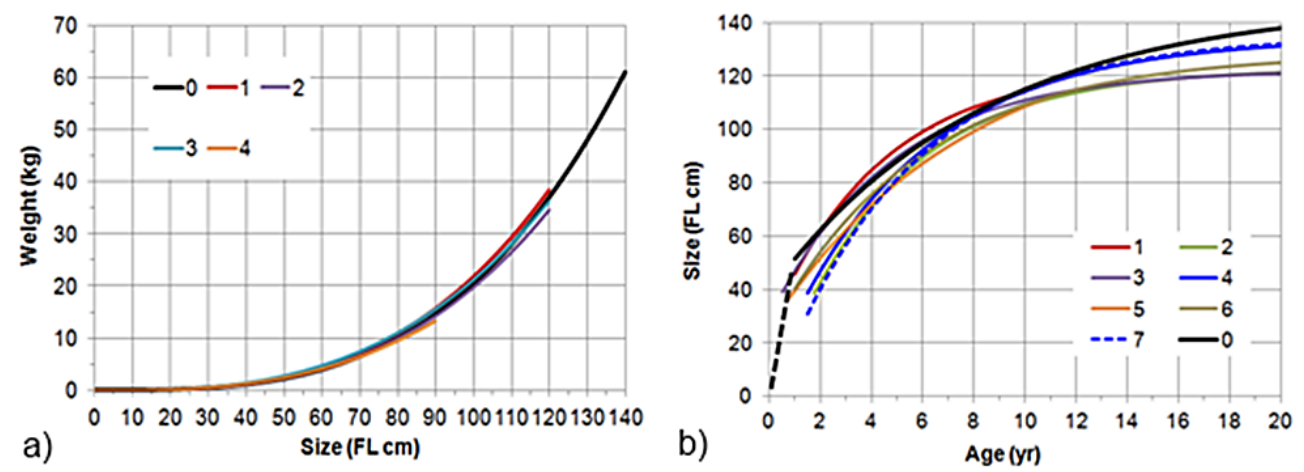

Figure 5. Left: South Pacific size-at-age (top) and weight-at-length (bottom) relationships used in SEAPODYM simulation (black curve) compared to other functions proposed in the literature. Right: population structure (average 1971-2000) in \% tonnes resulting from the optimization with SEAPODYM and the NCEP-ORCA2-PISCES environmental forcing. References for weight at size: (0) this study (Hoyle and Davies (2009) for South Pacific albacore), (1) Santiago (1993) for North Atlantic albacore, (2) Penney (1994) for South Atlantic albacore, (3) Chen et al. (2010) for North Pacific albacore, and (4) Megalofonou (1990) for Mediterranean albacore. References for size at age: (0) this study (adapted from MULTIFAN estimate in Santiago and Arrizabalaga (2005), (1) Bard (1981), (2) ICCAT (1996), (3) Santiago and Arrizabalaga (2005), (4) Bard (1973), (5) Gonzales-Garces (1983), (6) Fernandez (1992), and (7) Yang (1970).

the end of summer-autumn towards the subtropical region in winter (Fig. 6). Young immature fish distributed along a southwest-northeast axis north of the main spawning ground and reaching the Bay of Biscay and adjacent waters, where they were exploited by surface fisheries. These features agree well with the knowledge on this species as described in the literature (Le Gall, 1974; Nishikawa et al., 1985; Arrizabalaga et al., 2004; Goni and Arrizabalaga, 2005; ICCAT, 2010).

The total biomass was estimated to have fluctuated between 900000 and $600000 \mathrm{t}$ over the historical fishing period 1960-2008 (Fig. 7). After a decreasing trend from the early industrial fishing period until the late 1970s, the biomass was estimated to stabilize then increase from the 1990s due to the release of fishing pressure by the longline fisheries and more favorable recruitment conditions.

\section{Validation}

The catch, CPUE (Catch Per Unit of Effort) and size frequencies of catch are predicted by the model using the observed fishing effort, a catchability coefficient and a selectivity function estimated during the optimization process using a MLE approach (Senina et al., 2008). The cost functions for the MLE approach minimize the difference between predicted and observed CPUE and size frequencies from each fishery. Details of the optimization experiment in its evaluation are provided in Dragon et al. (2014). Other recent applications of this approach to tuna species can be found in Senina et al. (2008), Lehodey et al. (2010b, 2013a) and Sibert et al. (2012).

Longline fisheries covered the entire tropical region and extend northwest to the temperate region, while French midwater trawl and French and Spanish troll fisheries extended offshore from the Bay of Biscay to $30^{\circ} \mathrm{W}$. The predicted catch fit the observed catch very well, both spatially and temporally, over the historical fishing period used for the simulation (Fig. 8). The fit was degraded only on the borders of the catch distribution, in relation to the low level of catch, and also likely the closed equatorial boundary. The best fit (correlation between monthly time series of prediction and observation: $r=0.95$ for catch and $r=0.93$ for CPUE) was obtained for the subtropical Taiwanese longline fishery (L4), which presented a high selectivity leading to the capture of large fish only. The worst fits were for fisheries L3 $(r=0.53$ and 0.66$)$ and $\mathrm{B} 13(r=0.72$ and 0.43$)$. However, despite relatively low correlation values of CPUE for Spanish bait boats (B13) and troll fisheries (T12: $r=0.52$ ), the seasonality was very well predicted. The low correlation values were due to the range of predicted variability being too small compared to observation. A more detailed analysis of the fit to data is provided in Dragon et al. (2014).

\section{Discussion}

The development of an ecosystem approach and models for the management of ocean marine resources requires multidisciplinary collaborations and easy access by researchers to standard validated data sets of historical catch data for the main exploited species. These data are essential both in order to include the impact of biomass removal by fisheries in the ecosystem models and to serve as the primary source for their evaluation. However, researchers involved in these developments do not necessarily have the background in fisheries sciences and the detailed knowledge on the history of the fisheries that are required to understand and use these data correctly. Here, we provide an example of a careful definition and validation of a fishing data set for the North Atlantic 
2nd Quarter
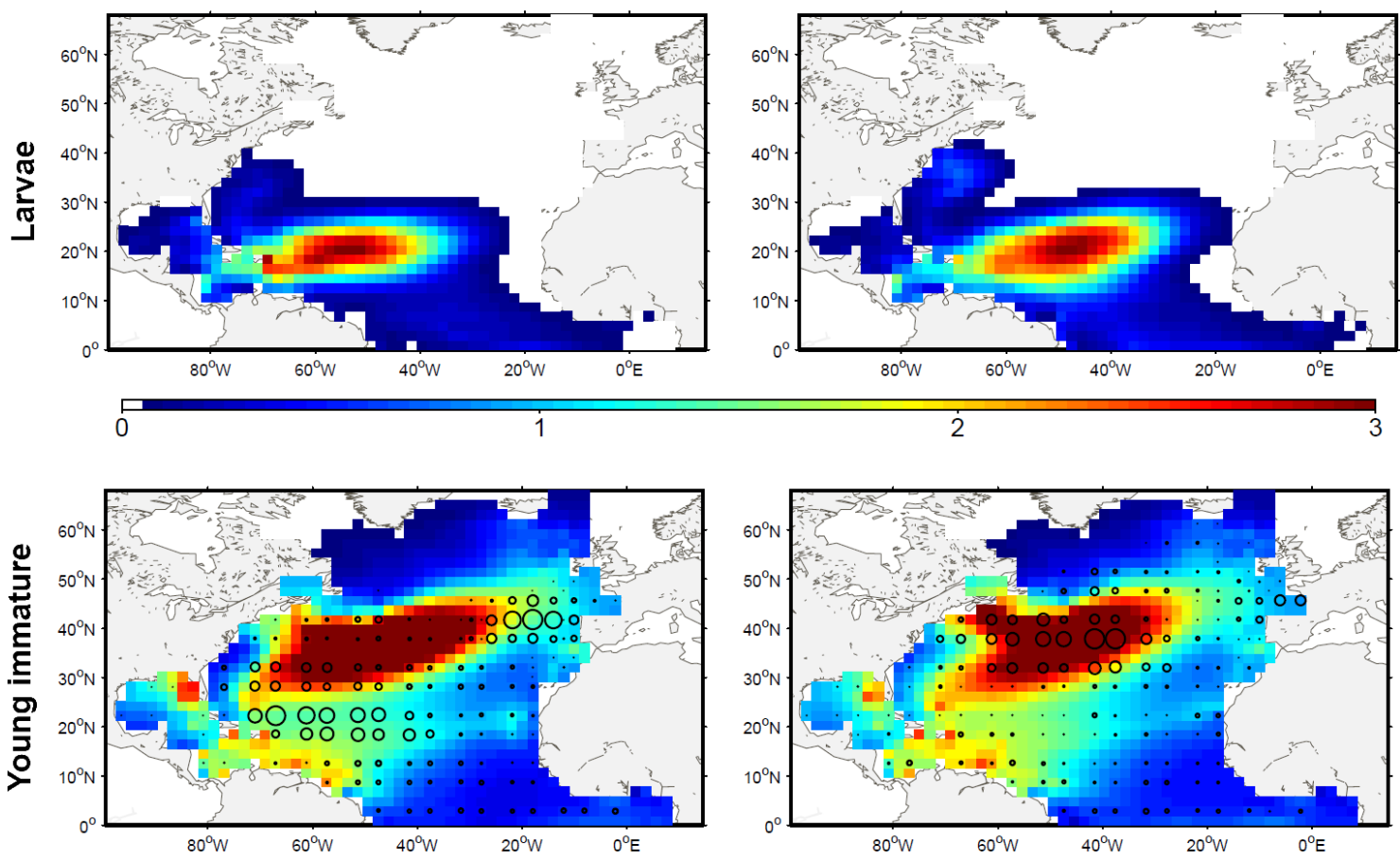

4th Quarter

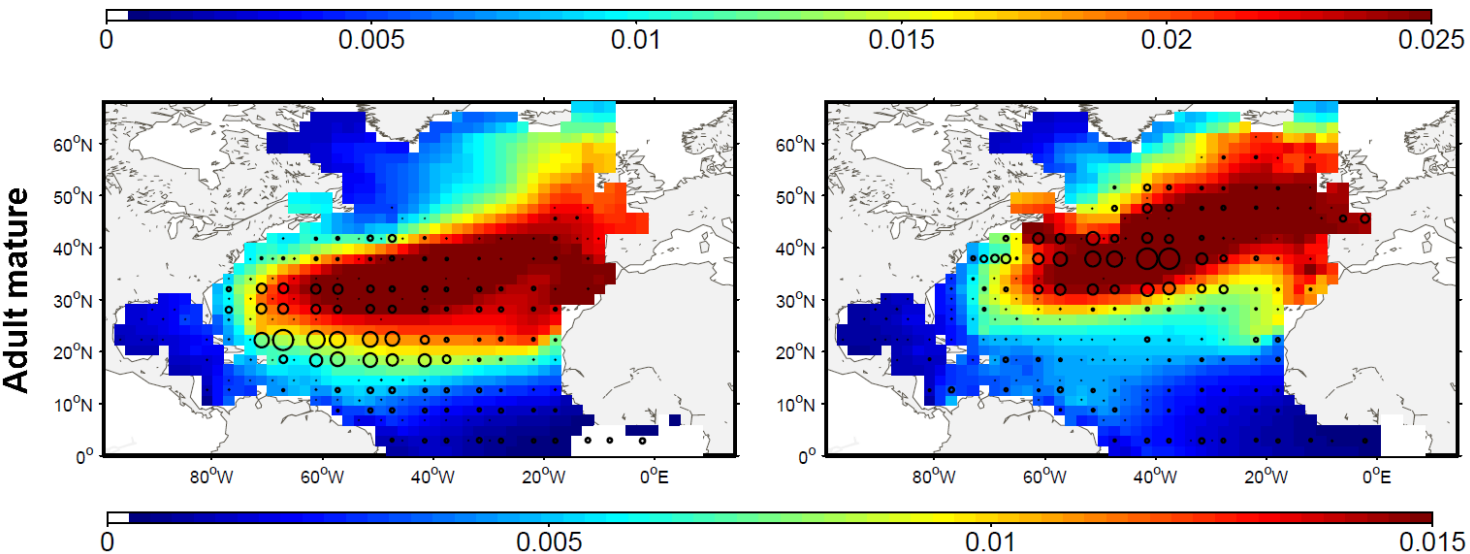

Figure 6. Seasonal average (1991-2000) distributions of North Atlantic albacore in the second (left) and fourth (right) quarter for larvae (no. $\mathrm{km}^{-2}$ ), young immature fish $\left(\mathrm{g} \mathrm{m}^{-2}\right)$ and adult mature fish $\left(\mathrm{g} \mathrm{m}^{-2}\right)$. Circles are proportional to observed catch. Fisheries selecting small size fish $(<85 \mathrm{~cm}$, T10 to B13) are superimposed on young fish distributions, and those selecting large size fish (> $85 \mathrm{~cm}$, L1 to L9) on adult fish distributions.

albacore for its use in a spatial ecosystem and population dynamics model.

While ecosystem models should take advantage of the progress in the 3-D simulations of the physics and chemistry of the ocean (e.g., http://www.myocean.eu/), the standard stock assessment studies often rely on temporal trends of fishing indicators over one or a few large geographical boxes, leading in some cases to a lack of data collection and sampling effort with which to build complete spatially explicit fishing data sets. In this study, the best spatially explicit distribution of catch, effort and size frequency of catch data was prepared from publicly available sources for North Atlantic albacore. However, despite that ICCAT developed a substantial effort to collect data of all tuna fisheries in the Atlantic Ocean, this geo-referenced data set only partially covers the total catch for this tuna stock. Though the level of coverage has increased in the more recent decades, it has always remained below $50 \%$ of the total declared catch. Now that ecosystem and spatially explicit models of population dynamics have been developed, priority should be given in the coming years to the preservation of existing data sets to increase this level of coverage as far as possible. Thereafter, 


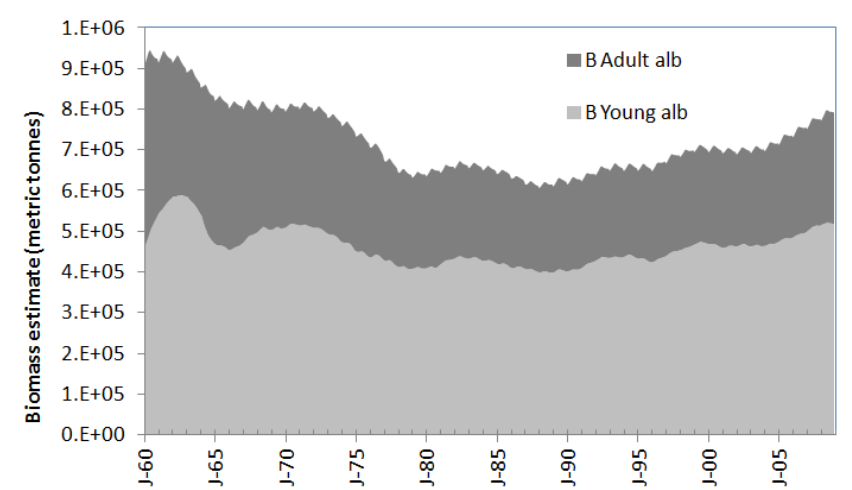

Figure 7. Total biomass estimate for young immature (light grey) and adult mature (dark grey) of the North Atlantic albacore stock.

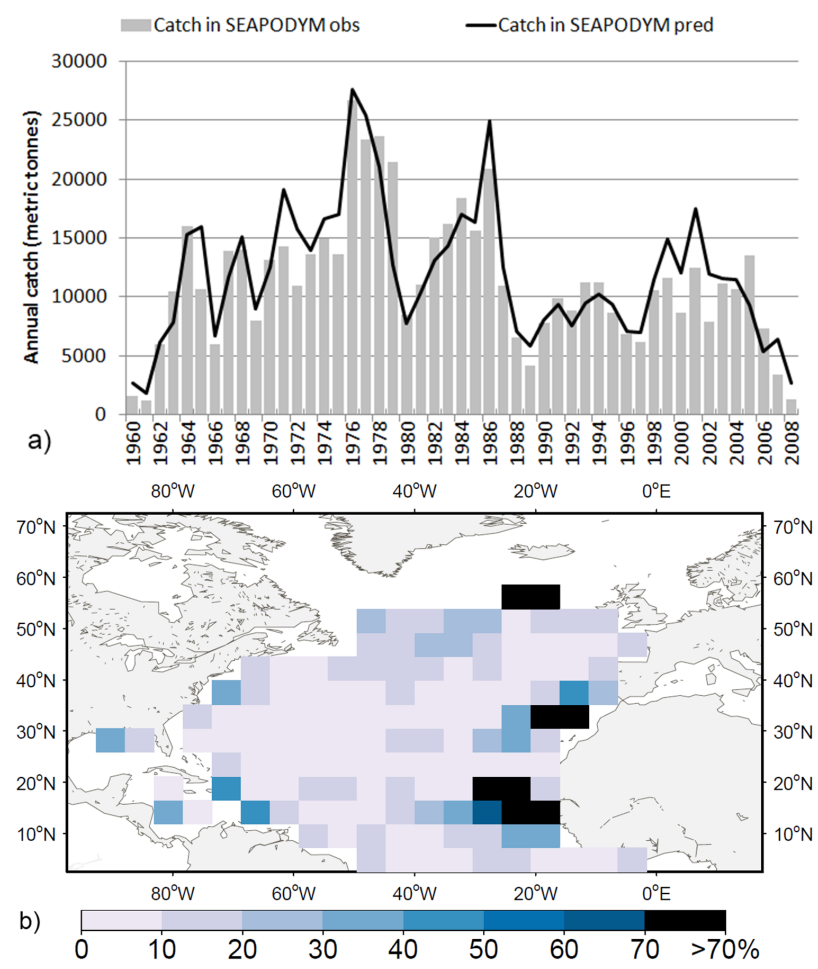

Figure 8. Fit to catch data. (a) Total annual predicted and observed catch used in SEAPODYM simulation. (b) Relative error in predicted catch aggregated in $5^{\circ}$ squares for the period 1960-2008.

a second geo-referenced data set should be built with all the necessary expertise and precautions to raise the catch data with positional information to the level of total catch. These products would therefore become useful standard data sets for the research community, allowing comparative studies and providing the best possible account of total fishing mortality over the entire historical fishing period. For the present and future years, an increase to $100 \%$ coverage of fisheries with geo-referenced data is essential and should be easily achieved with the development of vessel monitoring systems and electronic catch reporting.

On the modeling side, there are a range of uncertainties in the present results that were highlighted and discussed during the presentation of an earlier version of this work to the ICCAT working group on the stock assessment of Atlantic albacore (Lehodey et al., 2013b). It was thus concluded that these results were not yet ready to be used for management advice (ICCAT, 2013b). Though this modeling study has been then revised and described in more detail in Dragon et al. (2014), there are still uncertainties and large room for improvement.

To include the coastal domain, where a substantial amount of albacore tuna are caught, the spatial resolution needs to be increased. This is particularly true for the Bay of Biscay, where large surface fishery by French and Spanish fleets occur. The grid used in this study (ORCA2) gave a very crude representation of this area and consequently excluded a lot of fishing data from the shelf coast outside of the model domain. In addition, the coarse resolution used was inaccurate to simulate the oceanography in this particular area.

As noted above, the fishing mortality was likely underestimated in the simulation. However, it was not possible to estimate how the lack of direct fishing mortality impacted the stock estimation through the optimization process due to nonlinear mechanisms and compensatory mechanisms. Catch, CPUE and size frequency of catch observed at a given time and place are the result of past complex dynamics including all biomass removal by the fisheries. Therefore, even if these observations are partial, they provide hidden information on the state of the stock in the optimization approach that can modify the estimates of various parameters, especially regarding natural mortality and recruitment, as well as in the selectivity functions of fishing gears.

Nevertheless, this first spatially explicit estimate of the stock size, structure and biomass of North Atlantic albacore was provided together with fishing data to assist in the development of basin-scale ecosystem assessments. At basin scale, the application of the model SEAPODYM to the North Atlantic albacore tuna stock with the spatialized fishing data set provided realistic population dynamics under the influence of both environmental variability and fishing pressure, based on a robust statistical approach and a validation of model outputs (see also Dragon et al., 2014).

Regular updates should be provided when better environmental forcings and more-complete geo-referenced fishing data sets become available. In particular, a careful method for extrapolation from geo-referenced catch, effort and size frequency of catch by fishery needs to be developed to produce a spatially explicit data set of total fishing effort and catch. While this approach may introduce further biases due to under-sampled fleets and years, it seems indispensable to conduct a sensitivity analysis with such an extrapolated data set for quantifying the impact of this source of uncertainty on the estimates of biomass and derived management indices. 
Similar efforts should be invested for other major exploited species of the North Atlantic Basin (both large and small pelagic species).

Acknowledgements. We are grateful to ICCAT for the access to its public fishing database and particularly to Carlos Palma for his helpful advice on these data. This work was modified from a first analysis presented in 2013 to the ICCAT working group on the stock assessment of Atlantic albacore (reference SCRS/2013/125) and we are grateful to all the group members who provided useful comments that helped in the revision of this study. The authors also wish to thank Alain Fonteneau for his suggestions and helpful comments on a first version of the manuscript. The research leading to these results was supported by the European Commission FP7 EURO-BASIN (European Basin-Scale Analysis, Synthesis, and Integration; grant agreement no. 264933 ) and the Space Oceanography Division of CLS, France.

Edited by: G. Melvin

\section{Source data references}

Lehodey, P., Senina, I., Dragon, A.-C., and Arrizabalaga, H.: Spatially explicit estimates of stock size, structure and biomass of North Atlantic albacore Tuna (Thunnus alalunga) in the North Atlantic between 1956-2011 (ICCAT-L1), Collecte Localisation Satellites, doi:10.1594/PANGAEA.828115, 2014.

Lehodey, P., Senina, I., Dragon, A.-C., and Arrizabalaga, H.: Spatially explicit estimates of stock size, structure and biomass of North Atlantic albacore Tuna (Thunnus alalunga) in the North Atlantic between 1973-2011 (ICCAT-L2), Collecte Localisation Satellites, doi:10.1594/PANGAEA.828226, 2014.

Lehodey, P., Senina, I., Dragon, A.-C., and Arrizabalaga, H.: Spatially explicit estimates of stock size, structure and biomass of North Atlantic albacore Tuna (Thunnus alalunga) in the North Atlantic between 1987-2009 (ICCAT-L3), Collecte Localisation Satellites, doi:10.1594/PANGAEA.828227, 2014.

Lehodey, P., Senina, I., Dragon, A.-C., and Arrizabalaga, H.: Spatially explicit estimates of stock size, structure and biomass of North Atlantic albacore Tuna (Thunnus alalunga) in the North Atlantic between 1967-1986 (ICCAT-L4), Collecte Localisation Satellites, doi:10.1594/PANGAEA.828228, 2014.

Lehodey, P., Senina, I., Dragon, A.-C., and Arrizabalaga, H.: Spatially explicit estimates of stock size, structure and biomass of North Atlantic albacore Tuna (Thunnus alalunga) in the North Atlantic between 1967-1986 ICCAT-L5), Collecte Localisation Satellites, doi:10.1594/PANGAEA.828229, 2014.
Lehodey, P., Senina, I., Dragon, A.-C., and Arrizabalaga, Haritz: Spatially explicit estimates of stock size, structure and biomass of North Atlantic albacore Tuna (Thunnus alalunga) in the North Atlantic between 1987-2011 (ICCAT-L6), Collecte Localisation Satellites, doi:10.1594/PANGAEA.828230, 2014.

Lehodey, P., Senina, I., Dragon, A.-C., and Arrizabalaga, H.: Spatially explicit estimates of stock size, structure and biomass of North Atlantic albacore Tuna (Thunnus alalunga) in the North Atlantic between 1987-2011 (ICCAT-L7), Collecte Localisation Satellites, doi:10.1594/PANGAEA.828231, 2014.

Lehodey, P., Senina, I., Dragon, A.-C., and Arrizabalaga, H.: Spatially explicit estimates of stock size, structure and biomass of North Atlantic albacore Tuna (Thunnus alalunga) in the North Atlantic between 1974-1979 (ICCAT-L8), Collecte Localisation Satellites, doi:10.1594/PANGAEA.828232, 2014.

Lehodey, P., Senina, I., Dragon, A.-C., and Arrizabalaga, H.: Spatially explicit estimates of stock size, structure and biomass of North Atlantic albacore Tuna (Thunnus alalunga) in the North Atlantic between 1980-2009 (ICCAT-L9), Collecte Localisation Satellites, doi:10.1594/PANGAEA.828233, 2014.

Lehodey, P., Senina, I., Dragon, A.-C., and Arrizabalaga, H.: Spatially explicit estimates of stock size, structure and biomass of North Atlantic albacore Tuna (Thunnus alalunga) in the North Atlantic between 1967-2008 (ICCAT-T10), Collecte Localisation Satellites, doi:10.1594/PANGAEA.828234, 2014.

Lehodey, P., Senina, I., Dragon, A.-C., and Arrizabalaga, H.: Spatially explicit estimates of stock size, structure and biomass of North Atlantic albacore Tuna (Thunnus alalunga) in the North Atlantic between 1999-2007 (ICCAT-T11), Collecte Localisation Satellites, doi:10.1594/PANGAEA.828235, 2014.

Lehodey, P., Senina, I., Dragon, A.-C., and Arrizabalaga, H.: Spatially explicit estimates of stock size, structure and biomass of North Atlantic albacore Tuna (Thunnus alalunga) in the North Atlantic between 1987-2005 (ICCAT-B12), Collecte Localisation Satellites, doi:10.1594/PANGAEA.828236, 2014.

Lehodey, P., Senina, I., Dragon, A.-C., and Arrizabalaga, H.: Spatially explicit estimates of stock size, structure and biomass of North Atlantic albacore Tuna (Thunnus alalunga) in the North Atlantic between 1987-2005 (ICCAT-B13), Collecte Localisation Satellites, doi:10.1594/PANGAEA.828237, 2014.

Lehodey, P., Senina, I., Dragon, A.-C., and Arrizabalaga, H.: Spatially explicit estimates of stock size, 
structure and biomass of North Atlantic albacore Tuna (Thunnus alalunga) in the North Atlantic between 1975-1984 (ICCAT-B14), Collecte Localisation Satellites, doi:10.1594/PANGAEA.828238, 2014.

Lehodey, P., Senina, I., Dragon, A.-C., and Arrizabalaga, H.: Compilation of Thunnus alalunga (North Atlantic Albacore) fork length frequencies in 1 centimeter intervals from catches in the North Atlantic between 1956-2010, Collecte Localisation Satellites, doi:10.1594/PANGAEA.828171, 2014.

Lehodey, P., Senina, I., Dragon, A.-C., and Arrizabalaga, H.: Compilation of Thunnus alalunga (North Atlantic Albacore) fork length frequencies in 2 centimeter intervals from catches in the North Atlantic between 1956-2010, Collecte Localisation Satellites, doi:10.1594/PANGAEA.828170, 2014.

Lehodey, P., Senina, I., Dragon, A.-C., and Arrizabalaga, H.: Compilation of Thunnus alalunga (North Atlantic Albacore) fork length frequencies in 5 centimeter intervals from catches in the North Atlantic between 1956-2010, Collecte Localisation Satellites, doi:10.1594/PANGAEA.828168, 2014.

\section{References}

Arrizabalaga, H., Costas, E., Juste, J., González-Garcés, A., Nieto, B., and López-Rodas, V.: Population structure of albacore Thunnus alalunga inferred from blood groups and tag-recapture analyses, Mar. Ecol. Prog. Ser., 282, 245-252, 2004.

Aumont, O. and Bopp, L.: Globalizing results from ocean in-situ iron fertilization studies, Global Biogeochem. Cy., 20, GB2017, doi:10.1029/2005GB002591, 2006.

Bard, F. X.: Le thon germon Thunnus alalunga (Bonaterre 1788) de l'Océan Atlantique. De la dynamique des populations à la stratégie démographique. Thèse de Doctorat d'Etat es Sciences Naturelles. University Pierre et Marie Curie, Paris. 336 pp., 1981.

Bard, F. X.: Etude sur le germon (Thunnus alalunga Bonaterre 1788) de l'Atlantique nord. Elements de dynamique de population. Thèse de Doctorat de 3ème cycle, University Pierre et Marie Curie, Paris, 125 pp., 1973.

Bopp, L., Aumont, O., Cadule, P., Alvain, S., and Gehlen, M.: Response of diatoms distribution to global warming and potential implications: A global model study, Geophys. Res. Lett., 32, L19606, doi:10.1029/2005GL023653, 2005.

Chen, K. S., Crone, P. R., and Hsu, C. C.: Reproductive biology of albacore Thunnus alalunga, J. Fish Biol., 77, 119-136. doi:10.1111/j.1095-8649.2010.02662.x, 2010.

Dragon, A.-C., Senina, I., Calmettes, B., Titaud, O., Conchon, A., Arrizabalaga, H., and Lehodey, P.: Modeling spatial population dynamics of North Atlantic Albacore tuna under the influence of both fishing and climate variability, Can. J. Fish Aquat. Sci., submitted, 2014.

Fernandez, M.: Révision des méthodes d'ageage du germon (Thunnus alalunga Bonn., 1788) nord est Atlantique par l'étude des pièces anatomiques calcifiées, Collect Vol. Sci. Pap. ICCAT, 39, 225-240, 1992.

Fonteneau, A.: Some comments upon the 2007 North Atlantic Albacore assessmentm SCRS/2007/155, Collect Vol. Sci. Pap. ICCAT, 62, 944-950, 2008.

Goni, N. and Arrizabalaga, H.: Analysis of juvenile North Atlantic albacore (Thunnus alalunga) catch per unit effort by surface gears in relation to environmental variables, ICES J. Mar. Sci., 62, 1475-1482, 2005.

Gonzales-Garces, A. and Fariña, A. C.: Determining age of young albacore, Thunnus alalunga, using dorsal spines, NOAA Technical Report NMFS, 8, 117-122, 1983.

Gorgues, T., Menkes, C., Aumont, O., Vialard, J., Dandonneau, Y., and Bopp, L.: Biogeochemical impact of tropical instability waves in the equatorial Pacific, Geophys. Res. Lett., 32, L24615, doi:10.1029/2005GL024110, 2005.

Hayashi, S., Honma, M., and Suzuki, Z.: A comment to rational utilization of yellowfin tuna and albacore stocks in the Atlantic Ocean, Bull. Far Seas Res. Lab., 7, 71-112, 1972.

Hoyle, S. and Davies, N.: Stock assessment of albacore tuna in the South Pacific ocean, WCPFC-SC5-2009/SA-WP-6, 129. Scientific Committee, Fifth Regular Session, 10-21 August 2009, Port Vila, Vanuatu, 2009.

ICCAT: Report of the Final Meeting of the ICCAT Albacore Research Program, Collect. Vol. Sci. Pap. ICCAT, 43, 1-140, 1996.

ICCAT: Report of the 2009 ICCAT Albacore Stock Assessment Session (Madrid, Spain, 13 to 18 July 2009), Collect. Vol. Sci. Pap. ICCAT, 65, 1113-1253, 2010.

ICCAT: Report of the 2013 ICCAT North and South Atlantic Albacore data preparatory meeting (Madrid, Spain - 22 to 26 April 2013), 68 pp., 2013a.

ICCAT: Report of the 2013 ICCAT North and South Atlantic Albacore Stock Assessment meeting. Sukarrieta, Spain, June, available at: http://www.iccat.int/Documents/Meetings/Docs/2013_ ALB_ASSESS_REP_ENG.pdf (last access: 3 September 2014), 17-24, 2013b.

Lam Hoai, T.: Gonades de germons Thunnus (Germo) alalunga (Cetti) 1777, prélevées pendant la campagne d'assistance aux thoniers (1967), Trav. Fac. Sci. Rennes, Ser. Océanogr. Biol., 3, 19-37, 1970.

Le Gall, J. Y.: Exposé synoptique des données biologiques sur le germon Thunnus alalunga (Bonaterre, 1788) de l'Océan Atlantique, Synopsis FAO sur les pêches, 109, 70 pp., 1974.

Lehodey, P., Senina, I., and Murtugudde, R.: A Spatial Ecosystem And Populations Dynamics Model (SEAPODYM) - Modelling of tuna and tuna-like populations, Prog. Oceanogr., 78, 304-318, 2008.

Lehodey, P., Murtugudde, R., and Senina, I.: Bridging the gap from ocean models to population dynamics of large marine predators: a model of mid-trophic functional groups, Prog. Oceanogr., 84, 69-84, 2010a.

Lehodey, P., Senina, I., Sibert, J., Bopp, L, Calmettes, B., Hampton, J., and Murtugudde, R.: Preliminary forecasts of population trends for Pacific bigeye tuna under the A2 IPCC scenario, Prog. Oceanogr., 86, 302-315, 2010b.

Lehodey, P., Senina, I., Calmettes, B., Hampton, J., and Nicol, S.: Modelling the impact of climate change on Pacific skipjack tuna population and fisheries, Clim. Change, 119, 95-109, $2013 \mathrm{a}$. 
Lehodey, P., Senina, I., Dragon, A.-C., and Arrizabalaga, H.: Modeling activities conducted under EURO-BASIN research project to develop SEAPODYM to the North Atlantic albacore tuna (Thunnus alalunga) ICCAT, Document SCRS/2013/125, 26 pp., $2013 b$.

Lengaigne, M., Madec, G., Menkes, C., and Alory, G.: The Impact of Isopycnal mixing on the Tropical Ocean Circulation, J. Geophys. Res., 108, 3345, doi:10.1029/2002JC001704, 2003.

Megalofonou, P.: Size distribution, length-weight relationships, age and sex of albacore (Thunnus alalunga) in the Aegean Sea, Collect Vol. Sci. Pap. ICCAT, 33, 154-162, 1990.

Nishikawa, Y., Honma, M., Ueyenagi, S., and Kikawa, S.: Average distribution of larvae of oceanic species of scombrid fishes, 1951-1981. Contribution of the Far Seas Fisheries Research Laboratory, Fishery Agency of Japan, 236, 1-99, 1985.

Penney, A.: Morphometric relationships, annual catch-at-size for South African-caught South Atlantic albacore (Thunnus alalunga), Collect Vol. Sci. Pap. ICCAT, 42, 371-382, 1994.
Santiago, J.: A new length-weight relationship for the North Atlantic albacore, Collect Vol. Sci. Pap., ICCAT, 40, 316-319, 1993.

Santiago, J. and Arrizabalaga, H.: An integrated growth study for North Atlantic albacore (Thunnus alalunga Bonn. 1788), ICES J. Mar. Sci., 62, 740-749, 2005.

Senina I., Sibert J., and Lehodey P.: Parameter estimation for basinscale ecosystem-linked population models of large pelagic predators: application to skipjack tuna, Prog. Oceanogr., 78, 319-335, 2008.

Sibert, J., Senina, I., Lehodey, P., and Hampton, J. L.: Shifting from marine reserves to maritime zoning for conservation of Pacific bigeye tuna (Thunnus obesus), P. Natl. Acad. Sci. USA, 109, 18221-18225, 2012.

Yang, R. T.: Studies of age and growth of Atlantic albacore and a critical review on the stock structure, China Fish Monthly, 213, 3-16, 1970. 